\title{
Isotopic variations of carbon and nitrogen and their implications on the conversion of Cerrado vegetation into pasture
}

Variações isotópicas de carbono e nitrogênio e suas implicações na conversão da vegetação do cerrado em pastagens Naelmo de Souza Oliveira ${ }^{1}\left(\mathbb{D}\right.$, Jolimar Antonio Schiavo ${ }^{1}$ (D), Miriam Ferreira Lima ${ }^{1}$ (), Lais Thomaz Laranjeira ${ }^{1}$ (D), Geisielly Pereira Nunes ${ }^{2}$ (D), Sidne Canassa da Cruz $^{1}$ (D)

\section{A B S T RAC T}

Conversions of natural vegetation into pasture can, in a short time, change the carbon stock and the natural abundance of $\delta^{13} \mathrm{C}$ in the soil. The objective of this study was to evaluate changes in carbon (C) and nitrogen (N) stocks, as well as in the natural abundance of $\delta^{13} \mathrm{C}$ and $\delta^{15} \mathrm{~N}$ of Argissolo Vermelho distrófico (Acrisol), in an area of natural vegetation and planted pasture in the Cerrado region of Aquidauana (MS), Brazil. In order to do this, an area of pasture (PA), cultivated for 25 years with Urochloa brizantha, and an area of natural vegetation (NV) were evaluated. Soil samples were collected at intervals of $0.05 \mathrm{~m}$ up to $0.60 \mathrm{~m}$ depth, and physical attributes, $\mathrm{C}$ and $\mathrm{N}$ stocks (CSt and NSt) and isotopic variations of $\delta^{13} \mathrm{C}$ and $\delta^{15} \mathrm{~N}$ of soil were determined. In the $0-0.05 \mathrm{~m}$ layer, the highest $\mathrm{C}$ and $\mathrm{N}$ stocks occurred in $\mathrm{NV}, 21.99$ and $1.9 \mathrm{Mg} \mathrm{ha}^{-1}$, respectively. In the conversion to PA, $14.62 \mathrm{Mg}$ $\mathrm{ha}^{-1}$ of CSt and $1.36 \mathrm{Mg} \mathrm{ha}^{-1}$ of NSt were lost in the $0-0.05 \mathrm{~m}$ layer. The area with PA had greater isotopic enrichment of $\delta^{13} \mathrm{C}$ in the layers of $0-0.05$ and $0.05-0.10 \mathrm{~m}$, with values of -18.3 and $-17.4 \%$, respectively, while in the other layers the isotopic values decreased with the mixture between $C$ of $\mathrm{C}_{3}$ and $\mathrm{C}_{4}$ plants. NV showed enrichment in the isotopic signals, in the layers from $0.25-0.30 \mathrm{~m}$ up to $0.40-0.45 \mathrm{~m}$, with values between -21.74 and $-21.54 \%$, respectively, which is characteristic of mixed vegetation of $\mathrm{C}_{3}$ and $\mathrm{C}_{4}$ plants. The values of $\delta^{15} \mathrm{~N}$ showed isotopic enrichment as depth increased, indicating greater mineralization of soil organic matter in both areas. The conversion of Cerrado into pasture and its consequent fragmentation causes negative impacts on the $\mathrm{C}$ and $\mathrm{N}$ sequestration and storage capacity, both in pasture and in natural vegetation.

Keywords: acrisol; isotopic composition; vegetation conversion; organic matter.

\begin{abstract}
RE S U M 0
As conversões de vegetação natural em pastagem podem, em um curto intervalo de tempo, alterar o estoque de carbono e a abundância natural de $\delta^{13} \mathrm{C}$ no solo. $\mathrm{O}$ objetivo deste trabalho foi avaliar alterações nos estoques de carbono (C) e nitrogênio ( $\mathrm{N}$ ) e na abundância natural de $\delta^{13} \mathrm{C}$ e $\delta^{15} \mathrm{~N}$ no Argissolo Vermelho distrófico (Acrisolo) em uma área de vegetação natural e pastagem plantada no Cerrado em Aquidauana (MS). Para isso, foram avaliadas uma área de pastagem (PA), cultivada durante 25 anos com Urochloa brizantha, e uma área de vegetação natural (VN). Foram coletadas amostras de solo em intervalos de profundidade de 0,05 $\mathrm{m}$ até $0,60 \mathrm{~m}$, e a partir delas foram determinados os atributos físicos, os estoques de C e $\mathrm{N}$ (EstC e EstN) e as variações isotópicas de $\delta^{13} \mathrm{Ce} \delta^{15} \mathrm{~N}$ do solo. Na camada de $0-0,05 \mathrm{~m}$, os maiores estoques de C e N ocorreram na VN; 21,99 e 1,9 $\mathrm{Mg} \mathrm{ha}^{-1}$, respectivamente. $\mathrm{Na}$ conversão para PA, 14,62 Mg ha ${ }^{-1}$ do EstC e 1,36 Mg ha-1 do EstN foram perdidos na camada de 0-0,05 m. A área com PA apresentou maior enriquecimento isotópico do $\delta^{13} \mathrm{C}$ nas camadas de $0-0,05$ e 0,05-0,10 m, cujos valores foram de $-18,3$ e $-17,4 \%$, respectivamente, enquanto, nas demais camadas, os valores isotópicos diminuíram com a mistura entre $C$ de plantas $C_{3}$ e $C_{4}$. A VN apresentou enriquecimento nos sinais isotópicos nas camadas $0,25-0,30$ até $0,40-0,45 \mathrm{~m}$, com valores entre $-21,74$ e $-21,54 \%$, respectivamente, o que é característico de vegetação mista de plantas $\mathrm{C}_{3}$ e $\mathrm{C}_{4}$. Os valores de $\delta^{15} \mathrm{~N}$ apresentaram enriquecimento isotópico de acordo com o aumento da profundidade, indicando maior mineralização da matéria orgânica do solo em ambas as áreas. A conversão do Cerrado em pastagem e, consequentemente, sua fragmentação, provoca impactos negativos na capacidade de sequestro e armazenamento do C e N, tanto na pastagem quanto na vegetação natural.
\end{abstract}

Palavras-chave: argissolo vermelho; composição isotópica; conversões da vegetação; matéria orgânica.

${ }^{1}$ Universidade Estadual de Mato Grosso do Sul - Aquidauana (MS), Brazil.

${ }^{2}$ Universidade Federal da Grande Dourados - Dourados (MS), Brazil.

Correspondence address: Naelmo de Souza Oliveira - Rodovia Graziela Barroso, km 12 - Zona Rural - Caixa postal 25 - CEP: $79200-000$ -

Aquidauana (MS), Brazil. E-mail: naelmo-95@hotmail.com

Conflicts of interest: the authors declare that there are no conflicts of interest.

Funding: Coordination for the Improvement of Higher Education Personnel - Brazil (CAPES) - Funding code 001, and Support Foundation for the Development of Education, Science and Technology of the State of Mato Grosso do Sul (FUNDECT).

Received on: 06/21/2020. Accepted on: 09/27/2020.

https://doi.org/10.5327/Z21769478845

(c) (i)

This is an open access article distributed under the terms of the Creative Commons license. 


\section{Introduction}

Brazilian Cerrado is an ecological hotspot with great diversity of species that are endemic, but vulnerable to anthropic modifications, which cause several environmental impacts and the disorderly conversion of original vegetation into land used by agriculture and livestock, one of the main factors of degradation of this ecosystem (Rocha et al., 2011; Silva and Bacani, 2017; Ozório et al., 2019). According to deforestation data gathered up to the year 2013 by TerraClass Cerrado - a project implemented by Instituto Nacional de Pesquisas Espaciais (Inpe) and Empresa Brasileira de Pesquisa Agropecuária (Embrapa) - , the remaining natural vegetation represents $54.5 \%$ of the total Cerrado area. Regarding the classes of anthropic use, planted pasture was the one with the highest predominance $(29.5 \%)$, which leads to the conclusion that this activity has great impact in Cerrado (Brasil, 2015).

Recent estimates predict an increase in deforestation in the Cerrado biome at an average annual rate of $0.34 \%$ to $0.5 \%$ ( 772 ha year-1 on average), particularly affecting forests and savannas (Sano et al., 2019; Alencar et al., 2020). Considering that Cerrado is a vegetation complex consisting of forest vegetation (riparian forest, gallery forest, dry forest and Cerradão), grassland vegetation (dirty grassland, clean grassland and rupestrian grassland) and savanna vegetation (Cerrado sensu stricto, Cerrado park, palm grove and vereda), the environmental impact of its deforestation will be even greater ( $\mathrm{Ri}$ beiro and Walter 2008). Specifically, the state of Mato Grosso do Sul has lost an average $17 \%$ of its native vegetation in the last 33 years, and the greatest losses occurred between the years 1985 and 1995, a period of expansion of livestock farming and agriculture in the state (Alencar et al., 2020).

The conversion of native vegetation for anthropic use, if poorly managed, can have negative effects on the carbon (C) and nitrogen (N) cycle. In Cerrado, the imbalance in $\mathrm{C}$ and $\mathrm{N}$ stocks is largely due to the replacement of the original vegetation with pasture, the main anthropic class of land use in the biome, which leads to changes in the physical and chemical attributes of soil organic matter (SOM), both in degree of oxidation and lability, and may result in the simultaneous release of large amounts of $\mathrm{C}$ and $\mathrm{N}$ accumulated in the vegetation, increasing the release of greenhouse gases (Carvalho et al., 2010; Dortzbach et al., 2015).

Changes in land use forms also alter the nature of the soil's $\mathrm{C}$ and $\mathrm{N}$ sources. $\mathrm{C}_{3}$ plants (typical in tree vegetation) and $\mathrm{C}_{4}$ plants (typical in Poaceae species) leave different isotopic values of $\mathrm{C}$ and $\mathrm{N}$ in organic matter, an indicator of the type of existing vegetation and the modifications to which an area has been subjected, which can be determined using isotopic techniques based on the natural abundance of ${ }^{13} \mathrm{C}\left(\delta \delta^{13} \mathrm{C}\right)$ and ${ }^{15} \mathrm{~N}\left(\delta^{15} \mathrm{~N}\right)$. These isotopic techniques have been widely used in studies on landscape transformations, since they presuppose that organic matter reflects the plant material from which it was derived, constituting an efficient method to iden- tify anthropic effects on the structure of ecosystems (Costa et al., 2009; Loss et al., 2014).

The objective of this work was to evaluate changes in $\mathrm{C}$ and $\mathrm{N}$ stocks, as well as in the natural abundance of $\delta^{13} \mathrm{C}$ and $\delta^{15} \mathrm{~N}$ in Argissolo Vermelho distrófico (Acrisol), in areas of natural vegetation and planted pasture (Urochloa brizantha) of the Cerrado region of Aquidauana (MS), Brazil.

\section{Materials and Methods}

The study was carried out at Universidade Estadual do Mato Grosso do Sul, Aquidauana unit, located in the municipality of Aquidauana, Mato Grosso do Sul, at 20²7’20" S latitude and $55^{\circ} 40^{\prime} 17^{\prime \prime}$ W longitude, with an altitude of approximately $180 \mathrm{~m}$ (Figure 1). The predominant soil class in the region is Argissolo Vermelho distrófico (Acrisol), with sandy loam textural class (Schiavo et al., 2010; Santos et al., 2018). According to Köppen's classification, the climate of the region is Aw, defined as sub-humid hot tropical, with an average annual rainfall of $1,200 \mathrm{~mm}$, rainy season in summer and dry season in winter.

For the study, two areas were selected under two conditions of land use. The first was an area of planted pasture (PA) for cattle grazing in the extensive system, implemented in 1973 and reformed in 2005, by removing Urochloa brizantha and planting Panicum maximum (Guinea grass), with no fertilizer application. In 2011, the pasture was reformed for the second time, removing Panicum maximum and replanting Urochloa brizantha cv. BRS Piatã, which remained in the sampled picket in 2015. The second, used as reference, was an area of natural Cerrado vegetation, with gallery forest, on the Fundo stream (NV) (Figure 2).

In each studied area, a representative plot of $10,000 \mathrm{~m}^{2}$ was demarcated, and one soil pit with dimensions of approximately $1 \times 1 \mathrm{~m}$ surface and $0.6 \mathrm{~m}$ depth was opened in a random position. In each of the soil pits, undisturbed samples were collected using a volumetric ring, taking one sample every $5 \mathrm{~cm}$ deep. Leaf samples were also collected from the main plant species of the NV area - Anadenanthera colubrina, Anadenanthera peregrina, Bauhinia forficata, Cecropia sp., Xylopia sp. and Tabebuia sp. - and from Urochloa brizantha in the PA area. After collection, the soil samples were air dried, pounded to break up clods and passed through a 2-mm-mesh sieve, in order to obtain airdried fine earth (ADFE), which was subjected to the physical analyses (Teixeira et al., 2017).

Bulk density $(\mathrm{BD})$ was determined using the volumetric ring method (Teixeira et al., 2017). Particle density (PD) was determined by the volumetric flask method, and this data, together with $\mathrm{BD}$ data, was used to calculate the percentage of total porosity (TP).

$\mathrm{C}$ and $\mathrm{N}$ contents were determined by dry combustion in a CHNS analyzer (Elementar Analysensysteme $\mathrm{GmbH}$, Hanau, Germany). Data of $\mathrm{C}$ and $\mathrm{N}$ contents and $\mathrm{BD}$ were then used to calculate carbon 


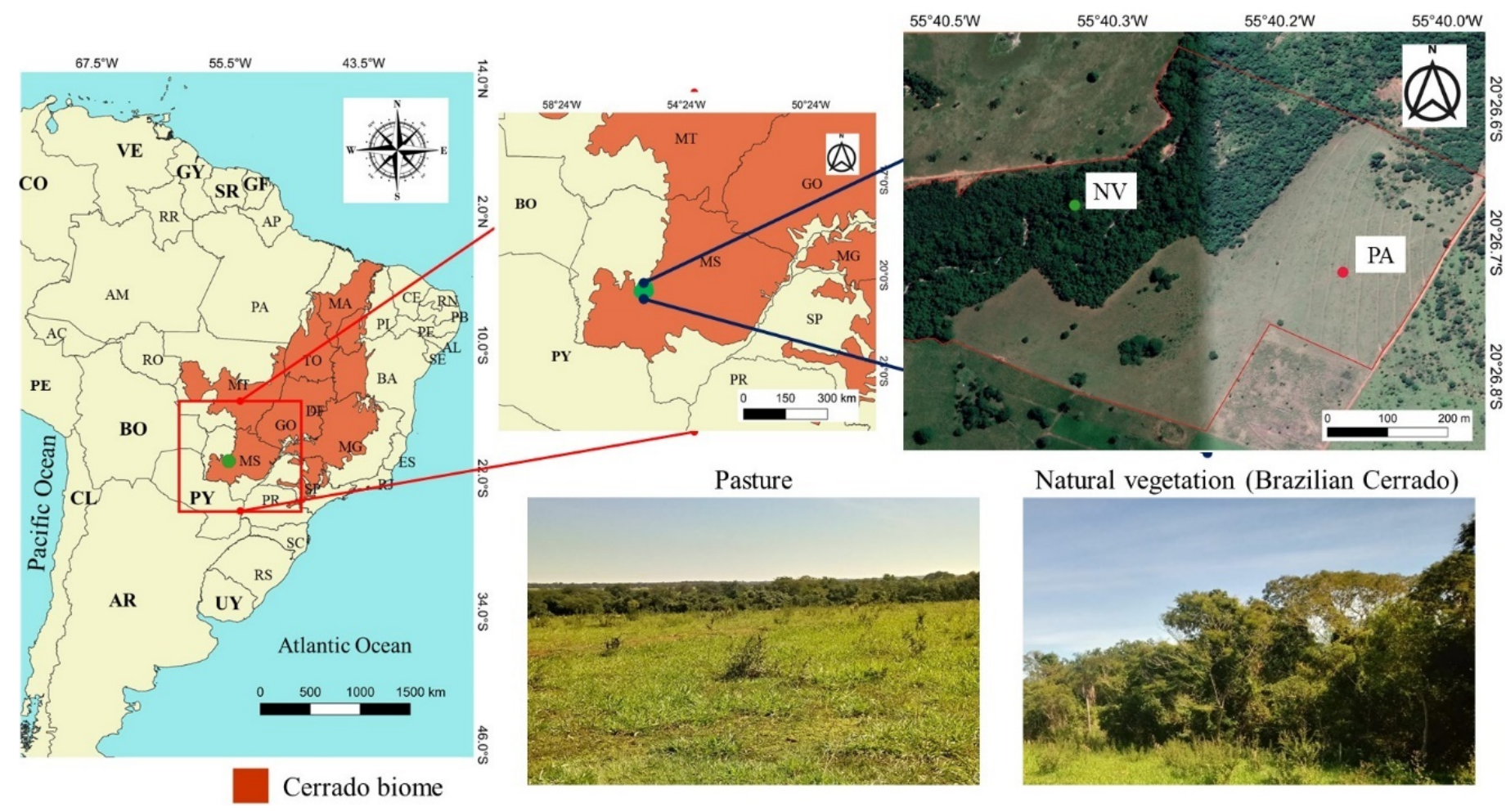

Figure 1 - Location of collection points in the natural vegetation (NV) of Cerrado and in the pasture area (PA), Mato Grosso do Sul, Brazil.

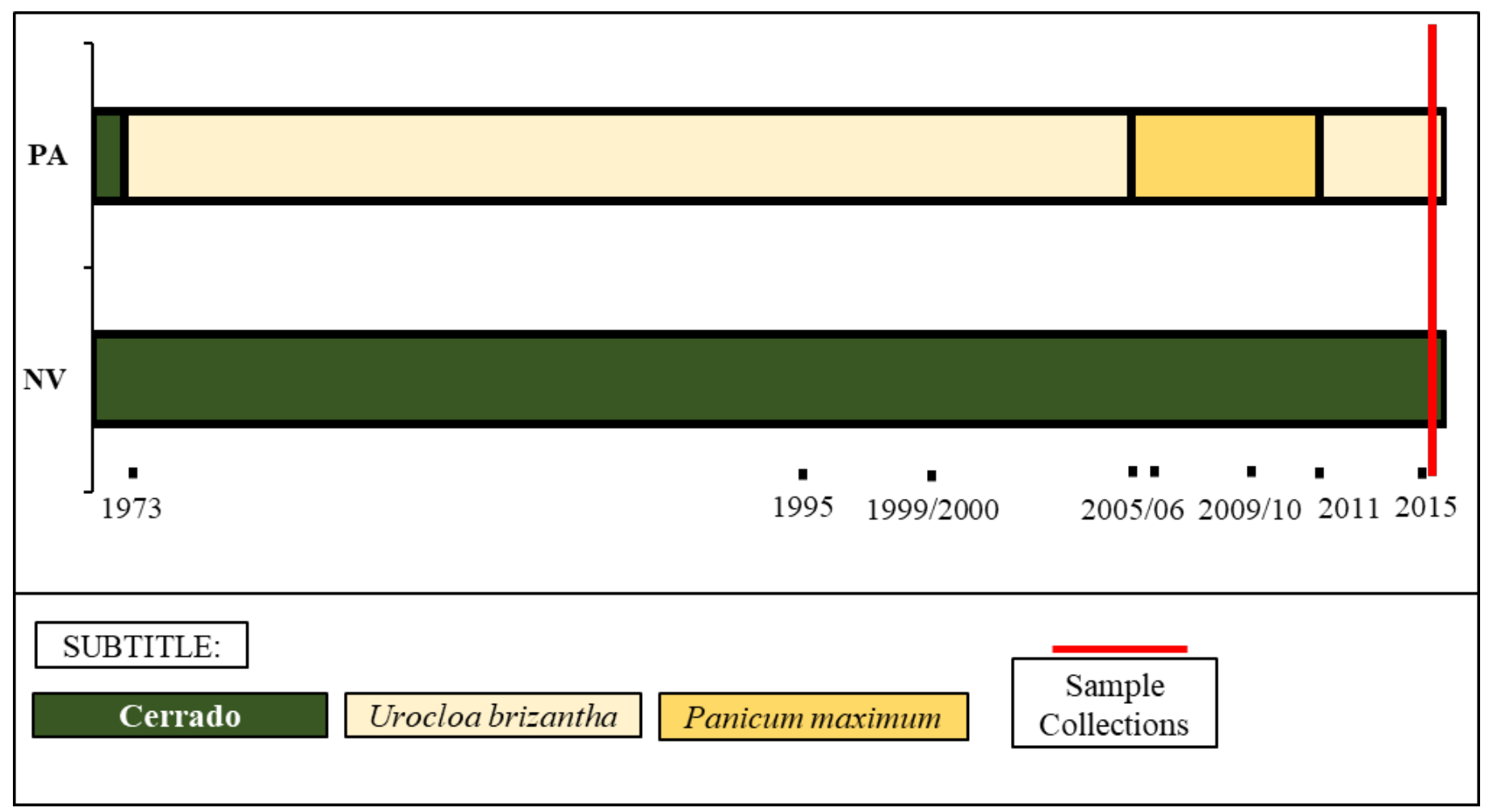

Figure 2 - History of land use change processes, with the respective dates for implementing of the areas: planted pasture (PA) and natural vegetation (NV), in the Cerrado biome in Mato Grosso do Sul, Brazil. 
(CSt) and nitrogen (NSt) stocks through the mathematical expression proposed by Veldkamp (1994) (Equation 1).

$$
S t=\frac{(E \times B D \times e)}{10}
$$

Where:

$\mathrm{St}=$ the stock of $\mathrm{C}$ or $\mathrm{N}$ in a given layer $\left(\mathrm{Mg} \mathrm{ha}^{-1}\right)$;

$\mathrm{E}=$ the total content of organic $\mathrm{C}$ or $\mathrm{N}$ in the sampled layer $\left(\mathrm{g} \mathrm{kg}^{-1}\right)$;

$\mathrm{BD}=$ the bulk density of the layer $\left(\mathrm{Mg} \mathrm{m}^{-3}\right)$;

$\mathrm{e}=$ the thickness of the layer considered $(\mathrm{m})$.

The natural abundance of ${ }^{13} \mathrm{C}$ and ${ }^{15} \mathrm{~N}$ was determined with the Finnigan Delta Plus mass spectrometer at the Isotopic Ecology Laboratory of CENA-USP, in Piracicaba-SP. The results of ${ }^{13} \mathrm{C}$ were expressed in the form of delta $\delta^{13} \mathrm{C}(\%)$, in relation to the international standard PDB (Belemnitella americana from the Pee Dee Formation). The results of ${ }^{15} \mathrm{~N}$ were expressed in the form of delta $\delta^{15} \mathrm{~N}(\%)$, in relation to the $\delta^{15} \mathrm{~N}$ of air $(0.3663 \%)$.

Isotopic dilution was calculated according to Equation 2, with the objective of identifying the percentage of carbon from $\mathrm{C}_{4}$ plants $\left(\% \mathrm{C}_{4}\right)$ :

$$
\% C_{4}=\frac{\delta^{13} C_{\text {Amostra }}-\delta^{13} C_{C 3}}{\delta^{13} C_{C 4}-\delta^{13} C_{C 3}} \times 100
$$

Where:

$\delta^{13} C_{\mathrm{C} 4}=$ the value of $\delta^{13} \mathrm{C}$ of the pasture $\mathrm{C}_{4}$ plant, Urochloa brizantha $(-13.33 \%$ );

$\delta^{13} C_{\mathrm{C} 3}=\delta^{13} \mathrm{C}$ of $\mathrm{C}_{3}$ plants, averages of species of natural vegetation $(-31.77 \%$ o

The percentages of remaining carbon from native vegetation $\left(\mathrm{C}_{\mathrm{f}}\right)$ were obtained through Equations 3 and 4:

$$
\begin{aligned}
& C_{p}=\frac{\delta^{13} C_{P A}-\delta^{13} C_{N V}}{\delta^{13} C_{C 4}-\delta^{13} C_{N V}} \times 100 \\
& C_{f}=100-C_{p}
\end{aligned}
$$

Where:

$\delta^{13} C_{\mathrm{PA}}=\delta^{13} \mathrm{C}$ of the soil sample analyzed;

$\delta^{13} C_{\mathrm{C} 4}=$ the value of $\delta^{13} \mathrm{C}$ of the pasture $\mathrm{C}_{4}$ plant, Urochloa brizan tha $(-13.33 \% 0)$;

$\delta^{13} C_{\mathrm{NV}}=$ the value of $\delta^{13} \mathrm{C}$ of the soil underforest (Balbinot, 2009).

Pearson's correlation and multiple linear regression analyses were performed. Statistical analyses were carried out using Microsoft Excel.

\section{Results and Discussion}

\section{Physical attributes}

Bulk density (BD) showed an increase in subsurface trend, with higher values in the PA area, ranging from 1.72 to $1.83 \mathrm{Mg} \mathrm{m}^{-3}$ in the layers from $0-0.05$ to $0.45-0.50 \mathrm{~m}$, respectively, whereas, in the $\mathrm{NV}$ area, values ranged from 1.45 to $1.72 \mathrm{Mg} \mathrm{m}^{-3}$ in the layers of $0.05-0.10$ and $0.50-0.55 \mathrm{~m}$, respectively (Figure 3 ). The total porosity of the soil (TP) was higher in the NV area, ranging from 41.4 to $30 \%$ in the layers of 0.05-0.10 and 0.40-0.45 m, respectively, when compared to the values of PA, which ranged from 30.4 to $28.4 \%$ in the layers of $0.05-0.10$ and $0.10-0.15 \mathrm{~m}$, respectively. The higher $\mathrm{BD}$ values and lower $\mathrm{TP}$ values in the PA area when compared to NV, both in surface and in subsurface, are probably attributed to the intense trampling of animals, often exceeding the adequate stocking rate, triggering the process of soil compaction (Ozório et al., 2019).

The increase of BD in subsurface is directly related to the reduction of organic matter contents, lower aggregation, lower root penetration, reduction of soil fauna activity, greater compaction caused by the weight of overlying layers, reduction of total porosity due to clay eluviation, among other processes (Reichert et al., 2007; Silva et al., 2011). These relationships are confirmed by the correlation analysis, where the BD values of the NV area showed negative correlations with TP $(r=-0.95)$, CSt $(r=-0.66)$ and NSt $(r=-0.70)$, and TP showed a positive correlation with CSt $(r=0.76)$ and NSt $(r=0.80)$ (Table 1$)$.

The values of $\mathrm{BD}$ in $\mathrm{PA}$ only showed negative correlation with porosity $(r=-0.81)$. The nonsignificant correlation with the attributes CSt and NSt can be explained by the intensification of compaction, resulting from the irregular management of the extensive livestock system, hampering the development of the pasture root system in subsurface, thus drastically reducing the contents of organic matter in subsurface (Ferreira et al., 2010).

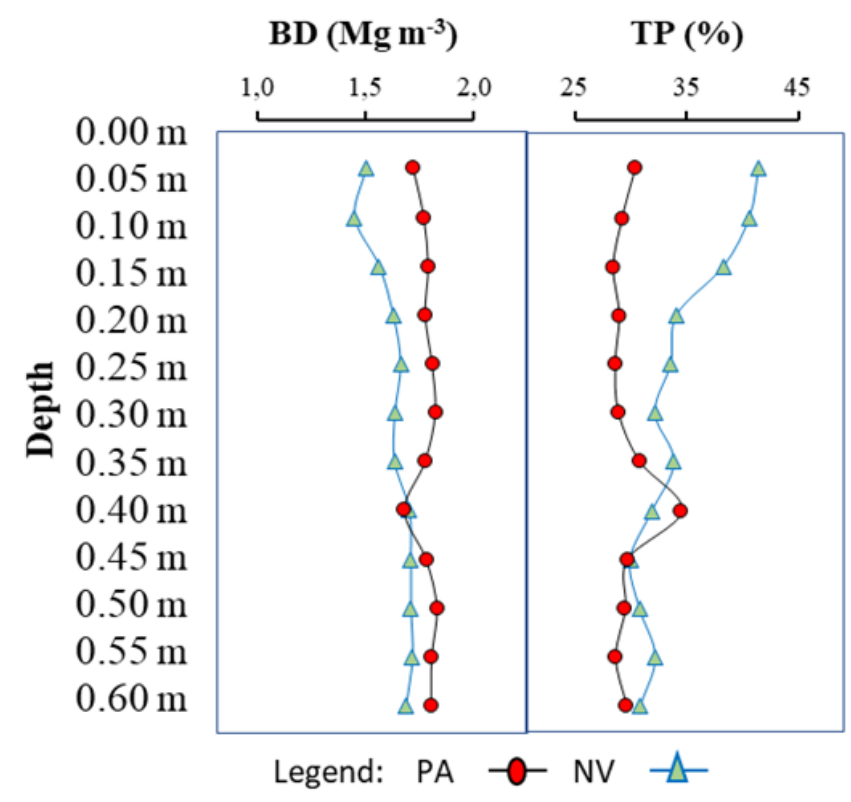

Figure 3 - Bulk density (BD) and total porosity (TP) of the soil in areas with planted pasture (PA) and natural vegetation (NV), in the Cerrado biome in Mato Grosso do Sul, Brazil. 


\section{Soil carbon and nitrogen stocks}

CSt and NSt in NV in the 0-0.05 m layer were 21.99 and $1.9 \mathrm{Mg} \mathrm{ha}^{-1}$, respectively, higher than those of the $\mathrm{PA}$ area in the same layer, which were 7.37 and $0.54 \mathrm{Mg} \mathrm{ha}^{-1}$, respectively. These differences between the stocks of $\mathrm{NV}$ and PA in this layer are equivalent to $14.62 \mathrm{Mg} \mathrm{ha}^{-1}$ of C and $1.36 \mathrm{Mg} \mathrm{ha}^{-1}$ of $\mathrm{N}$. No differences between the evaluated areas were observed in the other layers, and there was only a reduction in both contents in subsurface (Figure 4). The higher stocks of these elements in the NV area $(0-0.05 \mathrm{~m})$ can be attributed to the greater supply of litter causing greater entry of $C$ in the surface layers (Rosset et al., 2016). The density of tree species present in the NV area promotes higher quality of residues in the soil, which contributes to the results of stocks in the surface layer, mainly for NSt (Carvalho et al., 2017).

Many studies in the literature have shown that soils under well-managed pastures with good fertility conditions have $\mathrm{C}$ contents equal to or higher than those found in forest environments, due to the greater supply of organic matter provided by the roots, which explains similar C and $\mathrm{N}$ contents between the areas in subsurface (Carvalho et al., 2010; Rosset et al., 2016; Assunção et al., 2019; Falcão et al., 2020). However, the PA area is still under intensive grazing system, a common practice in the sandy soils of Cerrado, which results in the restriction of root system distribution and reduction in the accumulation of residues, consequently restricting the increment of $\mathrm{C}$ in subsurface, as observed in the PA area (Carvalho et al., 2010; Macedo et al., 2013).

The $\mathrm{PA}$ area had a higher $\mathrm{C} / \mathrm{N}$ ratio than the $\mathrm{NV}$ area in the layers from $0.05-0.10 \mathrm{~m}$ to $0.40-0.45 \mathrm{~m}$, with values from 14.10 to 14.63 , respectively, and a maximum of 17.13 in the $0.35-0.40 \mathrm{~m}$ layer. Because it has a higher content of lignin, a carbon-rich organic polymer, the pasture has organic matter with high $\mathrm{C} / \mathrm{N}$ ratio and difficult degradation, which contributes to the $\mathrm{C}$ values in subsurface being similar to or even higher than that of NV (Costa et al., 2009; Braz et al., 2013). However, the higher C

Table 1 - Pearson's correlation between the variables bulk density (BD), total porosity (TP) and carbon and nitrogen stocks (CSt and NSt) of the soil in areas in the Cerrado biome, Mato Grosso do Sul, Brazil.

\begin{tabular}{|l|c|c|c|c|}
\hline \multicolumn{5}{|c|}{ Natural vegetation (NV) } \\
\hline & BD & TP & CSt & NSt \\
\hline BD & 1 & & & \\
\hline TP & $-0.95^{\star *}$ & 1 & & \\
\hline CSt & $-0.66^{*}$ & $0.76^{* *}$ & 1 & \\
\hline NSt & $-0.70^{\star *}$ & $0.80^{* *}$ & $0.99^{* *}$ & 1 \\
\hline & & Pasture (PA) & & \\
\hline & BD & TP & CSt & NSt \\
\hline BD & 1 & & & \\
\hline TP & $-0.81^{\star *}$ & 1 & & \\
\hline CSt & -0.30 & -0.20 & 1 & \\
\hline NSt & -0.26 & -0.26 & $0.96^{* *}$ & 1 \\
\hline
\end{tabular}

contents in the layers from $0.45-0.50 \mathrm{~m}$ up to $0.55-0.60 \mathrm{~m}$ of the $\mathrm{NV}$ area may be associated with the presence of coal, due to the history of regular fires in the Cerrado biome and the preservation of SOM in structures, or complexed with oxides and clay minerals, resulting in increased $\mathrm{C} / \mathrm{N}$ ratio at these depths (Costa et al., 2009; Sant-Anna et al., 2017).

\section{Natural abundance of ${ }^{13} \mathrm{C}$ and ${ }^{15} \mathrm{~N}$}

The values of $\delta^{13} \mathrm{C}(\%)$ reflect the current vegetation in each area (Figure 5). The NV area had the lowest values of $\delta^{13} \mathrm{C}(\%)$, with variation from $-26.9 \%$ o $(0-0.05 \mathrm{~m})$ to $-21.5 \%$ o $(0.30-0.35 \mathrm{~m})$. The isotopic values of the first layers of $\mathrm{NV}$ discriminate the predominance of $\mathrm{C}_{3}$ plants, resulting in the intensity of ${ }^{13} \mathrm{C}$, which is described in the literature with values of $\delta^{13} \mathrm{C}$ between $-33 \%$ and -22\%o (Tarré et al., 2001; Carvalho et al., 2017), confirmed by the percentages of $\% \mathrm{C}_{4}$ below $50 \%$ in the $0-0.05 \mathrm{~m}$ and $0.05-0.10 \mathrm{~m}$ layers.

From the layers of $0.25-0.30 \mathrm{~m}$ extending up to $0.40-0.45 \mathrm{~m}$, there was isotopic enrichment, with a difference greater than $4 \%$ from the surface and $\% \mathrm{C}_{4}$ greater than $50 \%$. Isotopic variations greater than $4 \%$ are associated with changes in plant communities (Saia et al., 2008). This result indicates that, in some past period, the existing vegetation was mixed and more open than the current one, or that it underwent anthropic interferences, such as wood extraction and introduction of exotic species of grass and cattle, resulting in the mixture of $\mathrm{C}_{3}$ plants (arboreal vegetation) and $\mathrm{C}_{4}$ plants (pasture) (Assad et al., 2013; Sant-Anna et al., 2017).

In the deeper layers, below $0.45-0.50$ and $0.55-0.60 \mathrm{~m}$, the enrichment remained below $4 \%$, with values of $\delta^{13} \mathrm{C}(\%)$ below $-22 \%$ and $\% \mathrm{C}_{4}$ less than $50 \%$. This enrichment in subsurface is due to the processes of decomposition and humification of organic matter, where ${ }^{12} \mathrm{C}$ is released in greater amount, which leads to an increase in the concentration of the enriched forms in ${ }^{13} \mathrm{C}$ compared to the recently incorporated organic matter (Boutton et al., 1998; Dortzbach et al., 2015).

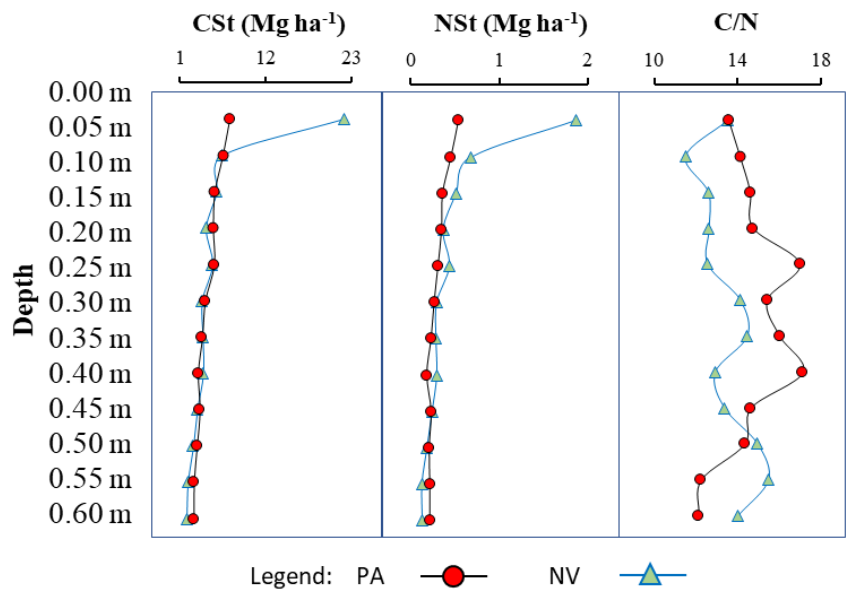

Figure 4 - Carbon stocks (CSt), nitrogen (NSt) and carbon/ nitrogen ratio $(\mathrm{C} / \mathrm{N})$ of the soil in areas with planted pasture (PA) and natural vegetation (NV), in the Cerrado biome, Mato Grosso do Sul, Brazil. 
The PA area had the highest values of natural abundance of $\delta^{13} \mathrm{C}(\%)$ in the $0-0.05$ and $0.05-0.10 \mathrm{~m}$ layers, with isotopic values from $-17.4 \%$ to $-18.3 \%$, respectively, and $\% \mathrm{C}_{4}$ higher than $70 \%$ at these depths, from the organic matter of $\mathrm{C}_{4}$ plants. These results indicate that there was considerable deposition of $\mathrm{C}_{4}$ plants derived from grass residues up to a depth of $0.10 \mathrm{~m}$ (Sant-Anna et al., 2017). In the other layers, the isotopic values decrease between $-19.0 \%$ and $-21.8 \%$, typical of vegetation mixed between $\mathrm{C}_{3}$ and $\mathrm{C}_{4}$ plants. Thus, it is possible to observe the evolution of $\mathrm{a}_{3}$ photosynthetic cycle vegetation to $\mathrm{C}_{4}$, but it still indicates that the organic matter in subsurface has remnants of the characteristics of transition from native vegetation to native pasture and of natural vegetation (Carvalho et al., 2010; Strey et al., 2016; Menezes et al., 2017).

The percentage of remaining $\mathrm{C}$ from native vegetation in the PA area (\%Cf) is below $40 \%$ in the first two layers, but these values increase dramatically in subsurface, exceeding $70 \%$ in most layers and reachg $91.7 \%$ in the $0.30-0.35 \mathrm{~m}$ layer. Some studies report similar results, with an average of $70 \%$ of soil organic carbon derived from the original forest in soils conducted from low-productivity pastures (Costa et al., 2009; Dortzbach et al., 2015).

The values of $\% \mathrm{Cf}$ in subsurface suggest the preservation of the remaining organic matter from $\mathrm{NV}$ in these layers, corroborating the results of the $\mathrm{C} / \mathrm{N}$ ratio at these same depths. The poorly formed pasture with high animal stocking rate in Argissolo with sandy texture resulted in a low carbon increment to the soil, associated with the rapid cycling of this material by microorganisms (Dortzbach et al., 2015). Argissolos or Acrisols (IUSS
Working Group WRB, 2015) tend to lose less C derived from the forest when compared to Ferralsols, due to their physical characteristics in the subsurface layers (Strey et al., 2016). The addition of fertilizer can lead to higher rates of decomposition of the remaining organic matter from natural vegetation and an increase in the release of $C$ from grasses (Sant-Anna et al., 2017). However, the area with PA has no fertilization management in its history, which restricts the development of the pasture root system and the decomposition of the remaining SOM in subsurface.

The values of $\delta^{15} \mathrm{~N}$ showed an isotopic enrichment as depth increased, and this pattern was more pronounced in NV. In the NV area, the values of $\delta^{15} \mathrm{~N}$ ranged from 3.99 to $16.83 \%$, whereas, in the PA area, there were values between 7.93 and $15.15 \%$ (Figure 5). The lower values of $\delta^{15} \mathrm{~N}$ in the surface layers, mainly in $\mathrm{NV}$, are attributed to the constant addition of organic matter in the surface layers of the soil, as well as to the diversity of sources present in NV, with some species of the Fabaceae family, which promotes higher contents of readily available nitrogen $\left({ }^{14} \mathrm{~N}\right.$, lighter isotope) (Loss et al., 2014).

The enrichment of $\delta^{15} \mathrm{~N}$ values in subsurface can also be attributed to transformations from organic $\mathrm{N}$ to mineral $\mathrm{N}$. Thus, as the reactions of mineralization, nitrification, denitrification and volatilization occur associated with $\mathrm{N}$ assimilations by plants, there is greater decomposition of the isotope ${ }^{14} \mathrm{~N}$, leaving the remaining organic matter enriched in ${ }^{15} \mathrm{~N}$ atoms (Couto et al., 2017). Therefore, isotropic values of $\delta^{15} \mathrm{~N}$ serve as an indication of the decomposition of organic matter, as the highest values of $\delta^{15} \mathrm{~N}$ are found in areas with low contents of organic carbon.

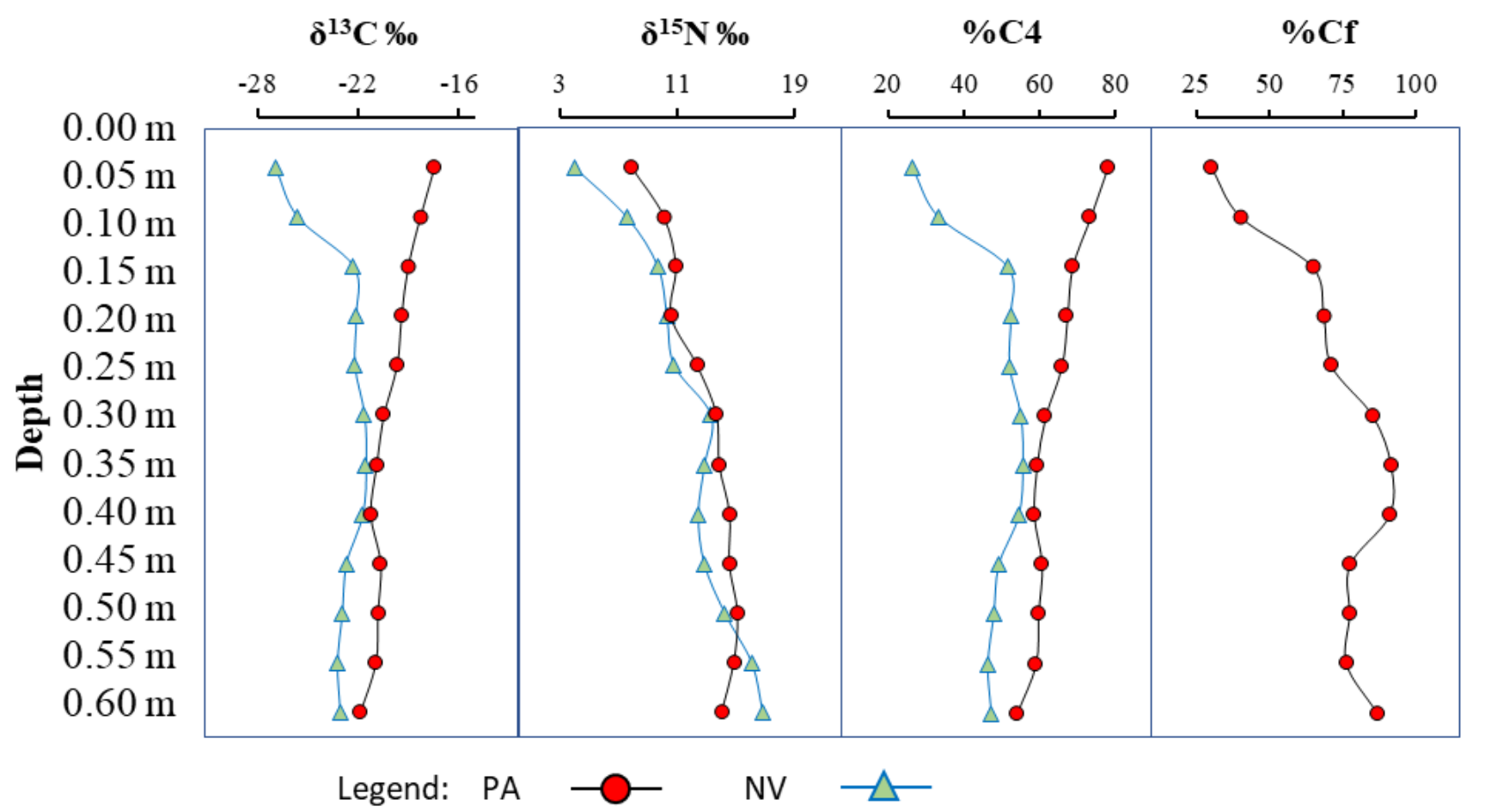

Figure 5 - Natural abundance of $\delta^{13} \mathrm{C}$ and $\delta^{15} \mathrm{~N}(\%)$, percentage of carbon from $\mathrm{C}_{4}$ plant origin (\%C4) and carbon remaining from native vegetation (\%Cf) in the soil of areas with planted pasture (PA) and Natural vegetation (NV), in the Cerrado biome, Mato Grosso do Sul, Brazil. 


\section{Effects of Cerrado conversion and fragmentation}

The conversion of native vegetation into cultivated pasture for extensive livestock farming in the 1970s, 1980s and 1990s, in the Cerrado area of Aquidauana, resulted in a fragmentation of this biome in the region, as it was shown in the NV area evaluated, with the fragmentation of natural vegetation in favor of the expansion of livestock farming and agriculture, a common practice in Cerrado, an ecological hotspot in Brazil (Silva and Bacani, 2017; Ozório et al., 2019; Alencar et al., 2020).

The NV area (fragmented area) possibly suffered or is still suffering from anthropic actions (introduction of animals, wood extraction and advance of pasture) and edge effect, factors that were not evaluated in the present study, as the collection was performed at the center of the $\mathrm{NV}$ area. However, the drastic reductions of CSt and NSt in subsurface and the isotopic enrichment in the layers of $0.25-0.30 \mathrm{~m}$ up to $0.40-0.45 \mathrm{~m}$ of NV may be associated with these factors (Nascimento and Laurance, 2004; Barros and Fearnside, 2016).

The fragmentation of NV may have resulted in a change in the composition and structure of the vegetation from edge to center, with death of climax trees and the development of pioneer species, affecting the distribution and dynamics of aboveground biomass, enabling the increase in the rate of decomposition and shifting the $\mathrm{C}$ flow to the soil (Barros and Fearnside, 2016; Ma et al., 2017). Thus, fragmentation contributed with negative impacts within biogeochemical cycles, such as reduction of the capacity of sequestration and storage of $\mathrm{C}$ and $\mathrm{N}$ in the vegetation, rapid mineralization of these elements in the soil, reduction of $\mathrm{C}$ and $\mathrm{N}$ stocks in surface and subsurface and, consequently, increase in greenhouse gas (GHG) emissions (Nascimento and Laurance, 2004).

\section{Conclusions}

The highest carbon and nitrogen stocks occur in the $0-0.05 \mathrm{~m}$ layer of natural vegetation, and conversion to pasture leads to significant losses in the carbon and nitrogen stocks of the $0-0.05 \mathrm{~m}$ layer. In the subsurface layers, the area of natural vegetation has similar contents to those of planted pasture.

The conversion of natural vegetation into pasture causes changes in the signal of $\delta^{13} \mathrm{C}$, with the highest isotopic values in the first two layers of pasture; however, in subsurface, the signals of $\delta^{13} \mathrm{C}$ decrease, indicating the presence of the mixture between $\mathrm{C}_{3}$ and $\mathrm{C}_{4}$ plants, and the percentage of remaining carbon from the native vegetation in the pasture area increases.

The enriched values of $\delta^{13} \mathrm{C}$ in a subsurface layer of natural vegetation suggest change in vegetation community in this area during past periods, with a mixed vegetation of $\mathrm{C}_{3}$ and $\mathrm{C}_{4}$ plants.

The values of $\delta^{15} \mathrm{~N}$ showed an isotopic enrichment as depth increased, indicating greater mineralization of soil organic matter. Because it was composed of $\mathrm{a} \mathrm{C}_{4}$ species, the area with pasture had the highest values of $\delta^{15} \mathrm{~N}$, with low enrichment in subsurface.

\section{Contribution of authors:}

Oliveira, N.S.: Conceptualization, Data curation, Formal analysis, Investigation, Methodology, Project administration, Resources, Software, Supervision, Validation, Visualization, Writing - original draft, Writing - review \& editing. Schiavo, J.A.: Conceptualization, Data curation, Formal analysis, Funding acquisition, Investigation, Methodology, Project administration, Resources, Supervision, Validation, Visualization, Writing - original draft, Writing - review \& editing. Lima, M.F.: Conceptualization, Data curation, Formal analysis, Investigation, Methodology, Project administration, Resources, Software, Visualization, Writing - original draft. Laranjeira, L.T.: Data curation, Formal analysis, Investigation, Methodology, Resources, Visualization, Writing - original draft. Nunes, G.P.: Data curation, Formal analysis, Investigation, Methodology, Resources, Visualization. Cruz, S.C.: Data curation, Formal analysis, Investigation, Methodology, Resources, Software, Visualization.

\section{References}

Alencar, A.; Shimbo, J.Z.; Lenti, F.; Balzani Marques, C.; Zimbres, B.; Rosa, M.; Arruda, V.; Castro, I.; Ribeiro, J.P.F.M.; Varela, V.; Alencar, I.; Piontekowski, V.; Ribeiro, V.; Bustamante, M.M.C.; Sano, E.E.; Barroso, M., 2020. Mapping Three Decades of Changes in the Brazilian Savanna Native Vegetation Using Landsat Data Processed in the Google Earth Engine Platform. Remote Sensing, v. 12, (6), 924. https://doi.org/10.3390/rs12060924.

Assad, E.D.; Pinto, H.S.; Martins, S.C.; Groppo, J.D.; Salgado, P.R.; Evangelista, B.; Vasconcellos, E.; Sano, E.E.; Pavão, E.; Luna, R.; Camargo, P.B.D., Martinelli, L.A., 2013. Changes in soil carbon stocks in Brazil due to land use: paired site comparisons and a regional pasture soil survey. Biogeosciences Discuss, v. 10, 5499-5533. http://dx.doi.org/10.5194/bgd-10-5499-2013.

Assunção, S.A.; Pereira, M.G.; Rosset, J.S.; Berbara, R.L.L.; García, A.C., 2019. Carbon input and the structural quality of soil organic matter as a function of agricultural management in a tropical climate region of Brazil. Science of The Total Environment, v. 658, 901-911. https://doi.org/10.1016/j. scitotenv.2018.12.271.
Balbinot, R., 2009. Carbono, nitrogênio e razões isotópicas $\delta^{13} \mathrm{C}$ e $\delta^{15} \mathrm{~N}$ no solo e vegetação de estágios sucessionais de Floresta Ombrófila Densa Submontana. Thesis, Universidade Federal do Paraná, Curitiba.

Barros, H.S.; Fearnside, P.M., 2016. Soil carbon stock changes due to edge effects in central Amazon forest fragments. Forest Ecology and Management, v. 379, 30-36. https://doi.org/10.1016/j.foreco.2016.08.002.

Boutton, T.W.; Archer, S.R.; Midwood, A.J.; Zitzer, S.F.; Bol, R., 1998. $\delta^{13} \mathrm{C}$ values of soil organic carbon and their use in documenting vegetation change in a subtropical savanna ecosystem. Geoderma, v. 82, (1-3), 5-41. https://doi. org/10.1016/S0016-7061(97)00095-5.

Brasil. 2015. Ministério do Meio Ambiente. Mapeamento do uso e cobertura do Cerrado: Projeto TerraClass Cerrado 2013. Ministério do Meio Ambiente.

Braz, S.P.; Urquiaga, S.; Alves, B.J.; Jantalia, C.P.; Guimarães, A.P.; Santos, C.A.; Santos, S.C.; Pinheiro, E.F.M.; Boddey, R.M., 2013. Soil carbon stocks under productive and degraded Brachiaria pastures in the Brazilian Cerrado. Soil Science Society of America Journal, v. 77, (3), 914-928. https://doi.org/10.2136/sssaj2012.0269. 
Carvalho, D.C.; Pereira, M.G.; Guareschi, R.F.; Maranhão, D.D.C., 2017. Estoque de Carbono e Nitrogênio e Abundância Natural de $\delta^{13} \mathrm{C}$ na Estação Ecológica de Pirapitinga, MG. Floresta e Ambiente, v. 24, e20150092. http:// dx.doi.org/10.1590/2179-8087.009215.

Carvalho, J.L.N.; Raucci, G.S.; Cerri, C.E.P.; Bernoux, M.; Feigl, B.J.; Wruck, F.J.; Cerri, C.C., 2010. Impact of pasture, agriculture and crop-livestock systems on soil C stocks in Brazil. Soil and Tillage Research, v. 110, (1), 175186. https://doi.org/10.1016/j.still.2010.07.011.

Costa, O.V.; Cantarutti, R.B.; Fontes, L.E.F.; Costa, L.M.D.; Nacif, P.G.S.; Faria, J.C., 2009. Estoque de carbono do solo sob pastagem em área de tabuleiro costeiro no sul da Bahia. Revista Brasileira de Ciência do Solo, v. 33, (5), 11371145. https://doi.org/10.1590/S0100-06832009000500007.

Couto, W.H.; Anjos, L.H.C.; Pereira, M.G.; Guareschi, R.F.; Assunção, S.A.; Wadt, P.G.S., 2017. Carbono, Nitrogênio, Abundância Natural de $\Delta^{13} \mathrm{C}$ e $\Delta^{15} \mathrm{~N}$ do Solo sob Sistemas Agroflorestais. Floresta e Ambiente, v. 24, e00117614. https://doi.org/10.1590/2179-8087.117614.

Dortzbach, D.; Pereira, M.G.; Blainski, É.; Paz González, A., 2015. Estoque de $\mathrm{C}$ e abundância natural de ${ }^{13} \mathrm{C}$ em razão da conversão de áreas de floresta $\mathrm{e}$ pastagem em bioma Mata Atlântica. Revista Brasileira de Ciência do Solo, v. 39, (6), 1643-1660. http://doi.org/10.1590/01000683rbcs20140531.

Falcão, K.S.; Monteiro, F.N.; Ozório, J.M.B., Souza, C.B.S.; Farias, P.G.S.; Menezes, R.S.; Panachuki, E.; Rosset, J.S., 2020. Estoque de carbono e agregação do solo sob diferentes sistemas de uso no Cerrado. Revista Brasileira de Ciências Ambientais (Online), v. 55, (2), 242-255. https://doi.org/10.5327/Z2176-947820200695.

Ferreira, R.R.M.; Tavares Filho, J.; Ferreira, V.M., 2010. Efeitos de sistemas de manejo de pastagens nas propriedades físicas do solo. Semina: Ciências Agrárias, v. 31, (4), 913-932.

IUSS Working Group WRB. 2015. World reference base for soil resources 2014, update 2015: International soil classification system for naming soils and creating legends for soil maps. World Soil Resources Reports, (106), 192.

Loss, A.; Pereira, M.G.; Perin, A.; Anjos, L.H.C., 2014. Abundância natural de $\delta{ }^{13} \mathrm{C}$ e $\delta{ }^{15} \mathrm{~N}$ em sistemas de manejo conservacionista no cerrado. Bioscience Journal, v. 30, (3), 604-615.

Macedo, M.C.M.; Zimmer, A.H.; Kichel, A.N.; Almeida, R.G.; Araújo, A.R., 2013. Degradação de pastagens, alternativas de recuperação e renovação, e formas de mitigação. In: 1. Encontro de Adubação de Pastagens da Scot Consultoria-TecFértil, Ribeirão Preto. Anais. Scot Consultoria, Bebedouro. pp. 158-181.

Ma, L.; Shen, C.; Lou, D.; Fu, S.; Guan, D., 2017. Ecosystem carbon storage in forest fragments of differing patch size. Scientific reports, v. 7, (1), 13173. https://doi.org/10.1038/s41598-017-13598-4.

Menezes, C.E.G.; Guareschi, R.F.; Pereira, M.G.; Anjos, L.H.C.; Correia, M.E.F; Balieiro, F.C.; Piccolo, M.D.C., 2017. Organic matter in areas under secondary forests and pasture. Cerne, v. 23, (3), 283-290. https://doi.org/10.1590/01047760201723032333.

Nascimento, H.E.; Laurance, W.F., 2004. Biomass dynamics in Amazonian forest fragments. Ecological Applications, v. 14, (sp. 4), 127-138. https://doi. org/10.1890/01-6003.

Ozório, J.M.B.; Rosset, J.S.; Schiavo, J.A.; Panachuki, E.; Silva Souza, C.B.; Silva Menezes, R.; Ximenes, T.S.; Castilho, S.C.P.; Marra, L.M., 2019. Estoque de carbono e agregação do solo sob fragmentos florestais nos biomas mata atlântica e cerrado. Revista Brasileira de Ciências Ambientais (Online), (53), 97-116. https://doi.org/10.5327/Z2176-947820190518.

Reichert, J.M.; Suzuki, L.E.A.S.; Reinert, D.J., 2007. Compactação do solo em sistemas agropecuários e florestais: identificação, efeitos, limites críticos e mitigação. Tópicos em Ciência do Solo, v. 5, 49-134.
Ribeiro, J.F.; Walter, B.M.T., 2008. As Principais Fitofisionomias do Bioma Cerrado. In: Sano, S.M.; Almeida, S.P.; Ribeiro, J.F. (Eds.), Cerrado: ecologia e flora. v. 2. EMBRAPA-Cerrados, Brasília. 876 pp.

Rocha, G.F.; Ferreira, L.G.; Ferreira, N.C.; Ferreira, M.E., 2011. Detecção de desmatamentos no bioma Cerrado entre 2002 e 2009: padrões, tendências e impactos. Revista Brasileira de Cartografia, v. 63, (3), 341-349.

Rosset, J.S.; Lana, M.D.C.; Pereira, M.G.; Schiavo, J.A.; Rampim, L.; Sarto, M.V.M., 2016. Frações químicas e oxidáveis da matéria orgânica do solo sob diferentes sistemas de manejo, em Latossolo Vermelho. Pesquisa Agropecuária Brasileira, v. 51, (9), 1529-1538. https://doi.org/10.1590/s0100-204x2016000900052.

Saia, S.E.M.G.; Pessenda, L.C.R.; Gouveia, S.E.M.; Aravena, R.; Bendassolli, J.A., 2008. Last glacial maximum (LGM) vegetation changes in the Atlantic Forest, southeastern Brazil. Quaternary International, v. 184, (1), 195-201. https://doi.org/10.1016/j.quaint.2007.06.029.

Sano, E.E.; Rosa, R.; Scaramuzza, C.A.M.; Adami, M.; Bolfe, E.L.; Coutinho, A.C.; Esquerdo, J.C.D.M.; Maurano, L.E.P.; Narvaes, I.S.; Oliveira Filho, F.J.B.; Silva, E.B.; Victoria, D.C.; Ferreira, L.G.; Brito, J.L.S.; Bayma, A.P.; Oliveira, G.H.; Bayma-Silva, G., 2019. Land use dynamics in the Brazilian Cerrado in the period from 2002 to 2013. Pesquisa Agropecuária Brasileira, 54. https:// doi.org/10.1590/s1678-3921.pab2019.v54.00138.

Sant-Anna, S.A.C.; Jantalia, C.P.; Sá, J.M.; Vilela, L.; Marchão, R.L.; Alves, B.J.; Urquiaga, S.; Boddey, R.M., 2017. Changes in soil organic carbon during 22 years of pastures, cropping or integrated crop/livestock systems in the Brazilian Cerrado. Nutrient Cycling in Agroecosystems, v. 108, (1), 101-120. https://doi.org/10.1007/s10705-016-9812-z.

Santos, H.G.; Jacomine, P.K.T.; Anjos, L.H.C.; Oliveira, V.A.; Lumbreras, J.F.; Coelho, M.R.; Almeida, J.A.; Araújo Filho, J.C.; Oliveira, J.B.; Cunha, T.J.F., 2018. Sistema Brasileiro de Classificação de Solos. 5a ed. Embrapa, Brasília, 531 pp.

Schiavo, J.A.; Pereira, M.G.; Miranda, L.P.M.D.; Dias Neto, A.H.; Fontana, A., 2010. Caracterização e classificação de solos desenvolvidos de arenitos da formação Aquidauana-MS. Revista Brasileira de Ciência do Solo, v. 34, (3), 881-889. https://doi.org/10.1590/S0100-06832010000300029.

Silva, L.F.; Bacani, V.M., 2017. Análise da Fragilidade Ambiental e das Áreas de Preservação Permanente da Bacia Hidrográfica do Córrego Fundo, Município de Aquidauana-MS. Caderno de Geografia, v. 27, (49), 264-284. https://doi. org/10.5752/P.2318-2962.2017v27n49p264.

Silva, R.F.D.; Guimarães, M.D.F.; Aquino, A.M.D.; Mercante, F.M., 2011. Análise conjunta de atributos físicos e biológicos do solo sob sistema de integração lavoura-pecuária. Pesquisa Agropecuária Brasileira, v. 46, (10), 1277-1283. https://doi.org/10.1590/S0100-204X2011001000023.

Strey, S.; Boy, J.; Strey, R.; Weber, O.; Guggenberger, G., 2016. Response of soil organic carbon to land-use change in central Brazil: a large-scale comparison of Ferralsols and Acrisols. Plant and Soil, v. 408, (1-2), 327-342. https://doi. org/10.1007/s11104-016-2901-6.

Tarré, R.; Macedo, R.; Cantarutti, R.B.; Rezende, C.P.; Pereira, J.M.; Ferreira. E.; Alves, B.J.R.; Urquiaga, S.; Boddey, R.M., 2001. The effect of the presence of a forage legume on nitrogen and carbon levels in soils under Brachiaria pastures in the Atlantic forest region of the South of Bahia, Brazil. Plant and Soil, v. 234, 15-26. https://doi.org/10.1023/A:1010533721740.

Teixeira, P.C.; Donagema, G.K.; Fontana, A.; Teixeira, W.G., 2017. Manual de métodos de análise de solo. $3^{\mathrm{a}}$ ed. Embrapa, Brasília. 573 pp.

Veldkamp, E., 1994. Organic carbon turnover in three tropical soils under pasture after deforestation. Soil Science Society of America Journal, v. 58, (1), 175-180. https://doi.org/10.2136/sssaj1994.03615995005800010025x. 